\title{
Title: Transcriptomic Profiling on Localized Gastric Cancer Identified CPLX1 as a Gene Promoting Malignant Phenotype of Gastric Cancer and a Predictor of Recurrence after Surgery and Subsequent Chemotherapy
}

Short title: $C P L X 1$ in gastric cancer recurrence after surgery and subsequent chemotherapy

5 Haruyoshi Tanaka, Mitsuro Kanda, Dai Shimizu, Chie Tanaka, Norifumi Hattori, Yoshikuni Inokawa, Masamichi Hayashi, Goro Nakayama, and Yasuhiro Kodera

Department of Gastroenterological Surgery, Nagoya University Graduate School of Medicine

Grant support: This study was funded by Taiho Pharmaceutical Co. Ltd

10 Acknowledgment We thank Taiho Pharmaceutical Co. Ltd for technical support, advice on this project through discussion on our result.

Keywords: Gastric cancer, Recurrence, Chemotherapy, Transcriptome, CPLXI

Abbreviations: EMT, epithelial-mesenchymal transition; mRNA, messenger RNA; OD, optical density; qRT-PCR, quantitative reverse-transcription polymerase chain reaction; RNAseq, RNAsequencing; siRNA, small interfering RNA; VC, vesicular cycle

Brief description: Transcriptomic analysis identified CPLX1 gene as a novel oncogene candidate for gastric cancer. CPLX1 may promote epithelial-mesenchymal transition and evading apoptosis of gastric cancer cells even under a cytotoxic agent, and also be a predictor for recurrence after surgery for UICC Stage II-III gastric cancer.

20 Correspondence: Dr. M. Kanda, Department of Gastroenterological Surgery (Surgery II), Nagoya University Graduate School of Medicine, 65 Tsurumai-cho, Showa-ku, Nagoya 466-8550, Japan Tel: +81-52-744-2249, Fax: +81-52-744-2252, E-mail: m-kanda@med.nagoya-u.ac.jp

Disclosures: The authors declare no conflicts of interest.

\section{Author Contributions:}

25 Study concept and design; MK and YK.

Acquisition of data; MK, HT, DS, and YK.

NOTE: This preprint reports new research that has not been certified by peer review and should not be used to guide clinical practice. 
medRxiv preprint doi: https://doi.org/10.1101/2021.03.25.21254204; this version posted March 28, 2021. The copyright holder for this

preprint (which was not certified by peer review) is the author/funder, who has granted medRxiv a license to display the preprint in It is made available under a CC-BY-NC-ND 4.0 International license .

Analysis and interpretation of data; HT, MK, and YK.

Drafting of the manuscript; HT, MK, and YK.

Critical revision of the manuscript for important intellectual content; HT, MK, SD, CT, NH, YI, MH, GN, and KY.

$5 \quad$ Statistical analysis; HT and MK.

Obtained funding; MK and YK.

Technical, or material support; HT, MK, DS, and CT.

Study supervision; YK.

\section{Abstract}

Localized gastric cancer (GC) becomes fatal once recurring. We still have room for improving their prognoses. Firstly, a transcriptomic analysis was done on surgically resected specimens of 16 patients with UICC stage III GC who underwent curative gastrectomy and adjuvant oral fluoropyrimidine monotherapy. Four of them were free from disease for longer than 5 years, and the others experienced metachronous metastasis at either liver, peritoneum, or distant lymph nodes $(\mathrm{n}=4$ each) within 2 years after surgery. CPLX1 was identified as a novel oncogene candidate for recurrence among 57,749 genes. Secondary, we tested alteration of malignant phenotypes including drug resistance of gastric cancer cell lines by small interfering RNA-mediated $C P L X 1$ knockdown. Inhibiting $C P L X 1$ expression decreased the proliferation, motility, and invasiveness of GC cells, and increased apoptosis and sensitivity to fluorouracil. Thirdly, we validated the clinical significance of $C P L X 1$ expression in GC by quantitative RT-PCR on 180 primary gastric cancer tissues of which patients underwent gastric resection for stage II and III GC without preoperative treatment between 2001 and 2014. Increased expression of CPLX1 mRNA in gastric cancer tissues correlated with worse prognoses and was an independent risk factor for peritoneal recurrence in subgroups receiving adjuvant chemotherapy. CPLX1 may represent a biomarker for recurrence of gastric cancer and a target for therapy. 
medRxiv preprint doi: https://doi.org/10.1101/2021.03.25.21254204; this version posted March 28, 2021. The copyright holder for this

preprint (which was not certified by peer review) is the author/funder, who has granted medRxiv a license to display the preprint in It is made available under a CC-BY-NC-ND 4.0 International license .

\section{Introduction}

Gastric cancer represents the third most leading cause of death among malignancies. ${ }^{1,2}$ Although the 5year overall survival rates vary from $20 \%$ to $50 \%$ depending on region, worldwide trends improved little or rather flat in this decade. ${ }^{1}$ At early stages, most cases of gastric cancer can be cured by surgical eradication. ${ }^{3}$ In order to improve outcomes of advanced, yet localized gastric cancer, it is critical how to minimize the risk of metachronous metastases. ${ }^{4}$ Perioperative chemotherapy or chemoradiotherapy were widely performed as standard therapy for these locally advanced diseases. ${ }^{5}$ However, there is no international consensus on regimens, and they often fail to prevent cancer from recurring. ${ }^{4,6}$

It is considered that recurring cancers have had already malignant phenotypes in primary lesion, such as invasiveness in peritoneal cavity or circulation, or cell survival under anoikis, or resistance to cytotoxic agents. Cancer cells recurring theoretically should have been separated from primary cancer tumors at the time of surgery. Once cancer cells detach from the primary lesion and are disseminated into the blood vessel, lymph vessel, or peritoneal cavity, they are simultaneously exposed to various selective pressure, such as hypoxia and anoikis. ${ }^{7}$ They would even be exposed to the induction of cytotoxic agents before long, and most disseminated cancer cells are considered to be extinct. Only subclones having certain malignant phenotypes could survive under selective pressure until their outgrowth.

Global genomic, epigenomic, and transcriptomic profiling, machine learning, and highthroughput biological screening with a bioinformatic approach have paved the way towards new insights on molecules demonstrating oncogenic phenotype including multidrug resistance. ${ }^{8}$ In particular, global profiling approaches possess the potential for us to discover novel therapeutic targets and biomarkers. ${ }^{9,10}$ However, many of these profiling seems to compare in terms of the UICC stages at the time of sampling, instead of respect to their therapeutic strategies and their outcomes of recurrent status. We hypothesized that primary cancer that recurs after surgery and adjuvant chemotherapy must have a divergent gene profile from those cases without recurrence. Here, we conducted next-generation RNA sequencing (RNA-seq) on gastric cancer limited to UICC-Stage III undergoing adjuvant chemotherapy with an oral fluorinated 
medRxiv preprint doi: https://doi.org/10.1101/2021.03.25.21254204; this version posted March 28, 2021. The copyright holder for this

preprint (which was not certified by peer review) is the author/funder, who has granted medRxiv a license to display the preprint in It is made available under a CC-BY-NC-ND 4.0 International license .

pyrimidine to identify the CPLXI as a driver oncogene candidate. CPLXI is a member of the Complexin/Synaphin family playing a key role in synaptic vesicle exocytosis, and dysfunction of the CPLX1 is associated with Developmental and epileptic encephalopathy- $63 .{ }^{11}$ To the best of our knowledge, however, this is the first study to have revealed malignant roles of CPLX1 in the outcome 5 of gastric cancer.

\section{Materials and methods}

\section{Sample collection}

For transcriptomic analysis, surgically resected specimens of 16 patients with stage III gastric cancer who underwent curative gastrectomy and adjuvant S-1 monotherapy were selected. These patients were categorized into two groups: those who were free from disease for longer than 5 years $(n=4)$ versus those who suffer from the liver, peritoneal, or distant nodal recurrences $(\mathrm{n}=4$ each) within 2 years after surgery. Global expressional data of the external dataset was obtained from KMplotter (https://kmplot.com/analysis/). ${ }^{12}$ Particularly, the data were retrieved from the GSE62254, GSE15459, GSE22377, GSE62254, GSE29272, GSE38749 limited to UICC stage II-III.

Gastric cancer cell lines (AGS, RRID is CVCL_0139; GCIY, CVCL_1228; IM95, CVCL_2961; KATOIII, CVCL_0371; MKN1, CVCL_1415; MKN7, CVCL_1417; MKN45, CVCL_0434; MKN74, CVCL_2791; N87, CVCL_1603; NUGC2, CVCL_1611; NUGC3, CVCL_1612; NUGC4, CVCL_3082; OCUM1, CVCL_3084; and SC-6-JCK, CVCL_F953) and the non-tumorigenic tubular epithelial cell line FHs74 (CVCL_2899) were obtained from the American Type Culture Collection (Manassas, VA, USA), the Japanese Collection of Research Bio Resources Cell Bank (Osaka, Japan), or were established at our institute. All cell lines were tested for mycoplasma, analyzed using the short tandem-repeat-polymerase chain reaction (PCR) method, and authenticated by the JCRB Cell Bank on June 30th, 2015. Cell lines were cultured at $37^{\circ} \mathrm{C}$ in RPMI 1640 medium (SigmaAldrich, St. Louis, MO, USA) supplemented with 10\% fetal bovine serum in an atmosphere containing $5 \% \mathrm{CO}_{2}$. 
medRxiv preprint doi: https://doi.org/10.1101/2021.03.25.21254204; this version posted March 28, 2021. The copyright holder for this

preprint (which was not certified by peer review) is the author/funder, who has granted medRxiv a license to display the preprint in It is made available under a CC-BY-NC-ND 4.0 International license .

Primary gastric cancer tissues were collected from 180 patients who underwent gastric resection of stage II and III gastric cancer without preoperative treatment at Nagoya University Hospital between 2001 and 2014. Since 2006, adjuvant oral fluoropyrimidine monotherapy has been recommended to all patients with stage II and III gastric cancer unless contraindicated. Primary gastric cancer tissue specimens were classified histologically according to the 7th edition of the Union for International Cancer Control (UICC) classification system and Japanese classification of gastric carcinoma (3rd edition) by two pathologists. This study conformed to the ethical guidelines of the World Medical Association Declaration of Helsinki Ethical Principles for Medical Research Involving Human Subjects. This study was approved by institutional review board at Nagoya University, Japan. Written informed consent was obtained from all patients for the use of clinical samples and data.

\section{Global expression profiling analysis}

Library preparation for RNA-seq was performed as described previously. ${ }^{13}$ To be brief, total RNAs (10 $\mu \mathrm{g}$ ) isolated from each of the surgically resected gastric tissues by the RNeasy Mini Kit (Qiagen, Hilden,

Germany). Only samples that passed the quality test by Agilent 2100 Bioanalyzer (Agilent, Santa Clara, CA, USA) were analyzed. Poly (A)-RNA was purified using oligo-dT beads, from which the cDNAs were synthesized, followed by adding 3'A. On the cDNAs, adaptors were ligated to be amplified by 15 cycles of PCR. Detailed RNA sequencing protocol was also described previously. ${ }^{13}$ Briefly, two runs per sample were performed with the paired-end method on the HiSeq sequencing system (Illumina, San

Diego, CA, USA). Then read mapping and quantification of gene expression were done. Mapping of the trimmed read was performed applying TopHat with annotations of GRCh37. Normalization of read counts of each gene was done with the TMM method, and the significance of their differences between the two groups (free from cancer for more than 5 years vs. early recurring cancer) were calculated with the Exact test in edgeR and TCC packages in R. In these packages, the moderated tagwise dispersion of the normalized read counts estimated by the quantile-adjusted conditional maximum likelihood method were used. ${ }^{14} P$ values were adjusted by applying Benjamini-Hochberg method with a false discovery 
medRxiv preprint doi: https://doi.org/10.1101/2021.03.25.21254204; this version posted March 28, 2021. The copyright holder for this

preprint (which was not certified by peer review) is the author/funder, who has granted medRxiv a license to display the preprint in It is made available under a CC-BY-NC-ND 4.0 International license .

rate of 0.5 .

Quantification of CPLXI expression by real-time reverse transcriptional PCR (qRT-PCR)

CPLX1 mRNA expression levels were determined using qRT-PCR as described previously. ${ }^{15}$ Briefly,

total RNAs $(10 \mu \mathrm{g})$ were isolated with the RNeasy Mini Kit (Qiagen) from each of the gastric cancer cell lines and surgically resected gastric cancer tissues, and their qualities were checked by measuring optical density (OD). cDNAs were generated from the RNAs and were amplified using specific PCR primers for CPLXI (Supplemental Table S1). A Sybr-Green PCR core reagents kit (Applied Biosystems, Foster City, CA, USA) was used to perform qRT-PCR. Initial denaturation at $95^{\circ} \mathrm{C}$ for $10 \mathrm{~min}, 50$ cycles at $95{ }^{\circ} \mathrm{C}$ for $10 \mathrm{~s}$, and $60{ }^{\circ} \mathrm{C}$ for $30 \mathrm{~s}$. All clinical samples were tested in technical triplicate.

\section{Knockdown of CPLXI expression using small interfering RNA (siRNA)}

$C P L X 1$-specific siRNA sequences were designed using two web-based tools; iScore Designer and siDirect; https://www.med.nagoya-u.ac.jp/neurogenetics/i_Score/i_score.html and http://sidirect2.rnai.jp/. siRNA specific for $C P L X 1$ or a control non-specific siRNA (40 nM of each) (Bioneer, Daejeon, Korea) were transiently transfected into gastric cancer cells using Neon ${ }^{\circledR}$ transfection system for OCUM1 or LipoTrust EX Oligo (Hokkaido System Science, Sapporo, Japan) for others. Seeding for all assays was done $24 \mathrm{~h}$ after transfection, which was performed on the next day of passage.

\section{Cell proliferation and apoptosis assay}

Cell proliferation was evaluated by measuring sequential cell viability using the Premix WST-8 Cell Proliferation assay kit (Dojindo Inc., Kumamoto, Japan) as described previously. ${ }^{16}$ Cancer cell lines $\left(5 \times 10^{3}\right.$ cells/well each) were seeded into $96-$ well plates. The OD of the solution at $450 \mathrm{~nm}$ in each well was measured 2 hours after the addition of $10 \mu \mathrm{L}$ of WST-8, and the fold-change in OD from the day of seeding (day 0) was evaluated. The assay was done in a technical quintuplicate. 
medRxiv preprint doi: https://doi.org/10.1101/2021.03.25.21254204; this version posted March 28, 2021. The copyright holder for this

preprint (which was not certified by peer review) is the author/funder, who has granted medRxiv a license to display the preprint in It is made available under a CC-BY-NC-ND 4.0 International license .

The detection of apoptotic status was evaluated with annexin-V staining as described previously. ${ }^{17}$ To be brief, cells are diluted in annexin-binding buffer and $10 \mu \mathrm{L}$ of annexin-V conjugate (Thermo Fisher Scientific). The cells were mounted on slides, and the apoptotic cells labeled fluorescently were counted under $\times 200$ magnification on BZ9000 (Keyence, Osaka, Japan). UVirradiated cells for $8 \mathrm{~h}$ followed by $16 \mathrm{~h}$ incubation in the normal condition was used as positive control.

\section{Cell migration and invasion assay}

The migration of AGS cells was tested in technical duplicate as described as previously, using CultureInsert 2 Well in $\mu$-Dish $35 \mathrm{~mm}$ (ibidi GmbH, Martinsried, Germany). ${ }^{18}$ Briefly, after $16 \mathrm{~h}$ passed from the seeding of AGS cells, the inserts were removed to establish cell-free gaps. The distances of cells were measured from both edges at 20 points per well. The mean widths of the cell-gap at the time of zero were adjusted to $580 \mu \mathrm{m}$ for equalization.

The ability of AGS cells to invade Matrigel matrix was determined in technical duplicate as described previously, using BioCoat Matrigel invasion chambers (BD Biosciences, Bedford, MA, USA).${ }^{19}$ AGS cells $\left(5 \times 10^{4}\right.$ cells/well $)$ were seeded into the upper well of the chamber in serum-free RPMI 1640 medium. After $48 \mathrm{~h}$, cells on the lower surface of the membrane were fixed, stained with Giemsa. The gross views of cell invasion were evaluated under $\times 40$ magnification.

\section{Drug sensitivity assay}

20 To test the influence of CPLX1 expression levels and knockdown effect on the resistance of gastric cancer cells to fluorouracil, we conducted drug sensitivity test as described previously. ${ }^{20}$ To be brief, AGS, KATOIII, MKN1, MKN45, N87, NUGC4, OCUM1 cells $\left(5 \times 10^{\wedge} 3\right.$ per well, 5 wells for each condition) were treated for 96 or $120 \mathrm{~h}$ with fluorouracil at final concentrations of 0 to $256 \mathrm{mg} / \mathrm{L}$. Cell viabilities were measured using the Cell Counting Kit-8 (Dojindo). In regard to data analysis, we evaluated drug sensitivity with normalized growth rate inhibition (GR) metrics, to minimize the perturbation of growth rate by treatment of siRNA. ${ }^{21} \mathrm{GR}$ value at a time $(t)$ under a drug at a 
medRxiv preprint doi: https://doi.org/10.1101/2021.03.25.21254204; this version posted March 28, 2021. The copyright holder for this

preprint (which was not certified by peer review) is the author/funder, who has granted medRxiv a license to display the preprint in It is made available under a CC-BY-NC-ND 4.0 International license .

concentration $(c)$ : GR $(c, t)=2^{\mathrm{k}(c, t) \mathrm{k}(0)}-1$, where $\mathrm{k}(c, t)$ is the growth rate of drug-treated cell and $\mathrm{k}(0)$ is that of the untreated control cells. That means that the GR value is the ratio of treated cell's growth rate to untreated cell's growth rate, both of which normalized by single-cell division. GR $=0$ means complete cytostasis and $\mathrm{GR}_{50}$ is the drug concentration where $\mathrm{GR}=0.5$.

\section{Exploring cancer-related genes cooperatively expressed with CPLXI and pathway analysis}

To explore genes that potentially interact with $C P L X 1$, we employed two array-based gene profiling assays. To see coexpression with CPLX1 mRNA expressional levels of EMT-related genes of 14 gastric cancer cell lines were quantified with the Human Epithelial to Mesenchymal Transition RT^2 Profiler PCR Array (Qiagen) following manufacture's protocol. ${ }^{22}$ In addition, to explore which pathways CPLXI is involved in, the PathScan Intracellular Signaling Array Kit (Product No. 7323, Chemiluminescent Readout) (Cell Signaling Technology, Danvers, MA, USA), which is based on the sandwich immunoassay principle, was applied following manufactures protocol. ${ }^{23} \mathrm{KATOIII}$ cells without treatment, treated by negative control siRNA (siControl) and siCPLXI were harvested to be tested. Antigen-Antibody complexes were detected with HRP-linked streptavidin through ImageQuant LAS 4000 (GE Healthcare, Chicago, IL, USA).

\section{Statistical analysis}

The significance of the difference between variables of two groups was assessed using the MannWhitney test or the Student's t-test for two valuables depending on their distribution. The Kruskal-Wallis test for three or more clinical valuables and pairwise t-test were applied for experimental values. Fisher's exact test was used to analyze categorical data of two groups. Overall survival and disease-free survival rates were calculated using the Kaplan-Meier method, and the differences between survival rates were evaluated by the Wilcoxon test. A $P$ value $<0.05$ was considered statistically significant. To calculate GR values, the GRmetrics package was applied. ${ }^{21}$ All statistical analyses except for some pipelines of the RNA-seq as mentioned above were performed with R software (The R Foundation for Statistical 
medRxiv preprint doi: https://doi.org/10.1101/2021.03.25.21254204; this version posted March 28, 2021. The copyright holder for this

preprint (which was not certified by peer review) is the author/funder, who has granted medRxiv a license to display the preprint in It is made available under a CC-BY-NC-ND 4.0 International license .

Computing, Vienna, Austria) version 4.0.1.

\section{Results}

RNA sequencing identified CPLXI as a study subject

5 Global expression profiling was performed to compare the expression levels of 57,749 genes of two groups; recurrent at liver, peritoneum, or distant lymph node vs. without recurrent over 5 years, where one sample of the case that recurred at the liver was excluded due to low quality. The total RNA had adequate quality as follows; 21.8 million pairs of mean reads were yielded per sample and the mean rate of $\geq Q 30$ was $95.0 \%$. We tested 57,749 genes if they were differentially expressed between postoperative cases with and without recurrence (Fig. 1a). Among 305 differentially expressed genes, CPLX1 was one of 12 genes of protein-coding and upregulated in the early recurrent group (Fig. 1a-c). As the predictive performance of CPLX1 was affirmed with external data sets (Supplemental Fig. 2a, 2b), we chose $C P L X 1$ as a candidate for oncogene and to be subject to further investigation.

\section{Inhibition of CPLX1 decreases malignant phenotypes of gastric cancer cells}

Expressional levels of CPLX1 mRNA were heterogeneous among gastric cancer cell lines and not detected in FHs74 (Fig. 2a). Four siRNAs were designed to determine the effect of knockdown on phenotypes (Supplemental Table S1). The knockdown effective ratio of siCPLXI-treated cells compared to untransfected cells ranged $0.168-0.266,0.341-0.418$, and $0.278-0.342$, for OCUM1, N87, and KATOIII cells respectively (Fig. 2b). The proliferation of AGS, MKN1, OCUM1, and KATOIII cells treated with siCPLX1 was significantly reduced compared to the untreated cells and those treated by siControl (Fig. 2c). At gross appearance through a phase-contrast microscope, we observed that AGS cells transfected by siCPLXI had cytoplasmic vacuolization in their cell cytoplasm (Fig. 2d). That seemed to indicate they were toward cell death ${ }^{24}$ so that we sought to quantify $C P L X 1$ promote apoptotic evasion. The proportions of annexin- $\mathrm{V}$ positive apoptotic cells were significantly increased by inhibition of CPLX1 expression on AGS, KATOIII, MKN1, and N87 cells (Fig. 2e, Supplemental Fig. 2a). 
medRxiv preprint doi: https://doi.org/10.1101/2021.03.25.21254204; this version posted March 28, 2021. The copyright holder for this preprint (which was not certified by peer review) is the author/funder, who has granted medRxiv a license to display the preprint in It is made available under a CC-BY-NC-ND 4.0 International license .

Additionally, to observe if siCPLX1 hampers cancer cells from epithelial-mesenchymal transition (EMT), we performed migration assay and invasion assay on AGS cells. Migrating distances of AGS cells were significantly reduced by siCPLXI (Fig. 2f). Also, fewer AGS cells treated by siCPLX1 passed through Matrigel chambers compared to AGS untreated or treated by siControl (Fig. 2g)

To test the possible role of $C P L X 1$ in chemotherapy-resistant, sensitivities to fluorouracil were tested on seven cell lines (Supplemental Fig. S2b). Although insignificant, there were weak correlations between the area under the curves of dose-response and CPLXI expression levels of these 7 cell lines (Supplemental Fig. S2c). CPLX1 inhibition increased sensitivities to fluorouracil of KATOIII, OCUM1, MKN1, and AGS cells (Fig. 3a). Regarding AGS cells, statistical modeling by GR metrics failed to generate a recognizable curve for AGS cells treated by siCPLXI, so that conventional dose-response curves and half-maximal inhibitory concentration $\left(\mathrm{IC}_{50}\right)$ values were presented.

We further explored genes that potentially interact with $C P L X 1$. Array-based PCR assay revealed that $E R B B 3, S O X 10, S N A I 3$, and $C T N N B 1$ were cooperatively expressed at a moderate level, of which rho ranged between 0.521 to 0.636 , with $C P L X 1$ among 14 gastric cancer cell lines (Fig. $3 \mathrm{~b}$ ). Also, array-based protein phosphorylation analysis showed siCPLX1 inhibited phosphorylation of Akt at thr308 and PRAS40 at Thr246 were weakly inhibited compared to both untransfected and transfected with siControl in KATOIII cells. Conversely, upregulation of phosphorated p38 at Thr180/Tyr182 and cleaved PARP at Asp214 were observed. (Fig. 3c)

\section{Overexpression of CPLX1 in tumor tissues predicts recurrence of gastric cancer}

Forty-five cases of 180 stage II-III gastric cancer patients were classified into a high CPLXI expression group according to the upper quantile value of the whole cohort $(C P L X 1 / G A P D H>0.06882)$. CPLX1 expression levels were independent of all clinicopathological variables of 180 patients of stage II-III gastric cancer except for tumor diameter and main tumor locations (Table 1). High CPLXI expression group had a poor overall-survival: 5-year survival rates were as low as 0.593 (95\% confidential interval: $0.460-0.763)$, compared to $0.744(0.665-0.832)$ for low $C P L X 1$ group $(P=0.025$, Fig. $4 a)$. High 
medRxiv preprint doi: https://doi.org/10.1101/2021.03.25.21254204; this version posted March 28, 2021. The copyright holder for this

preprint (which was not certified by peer review) is the author/funder, who has granted medRxiv a license to display the preprint in It is made available under a CC-BY-NC-ND 4.0 International license .

CPLX1 expression group also had shorter recurrence-free survival; 3-year survival rates were 0.514 (0.385-0.687), compared to $0.702(0.628-0.785)$ for low $C P L X 1$ group $(P=0.032$, Fig. $4 \mathrm{~b})$. To further investigate the association between $C P L X 1$ and resistance to adjuvant chemotherapy in terms of recurrence organs, we performed a subgroup analysis on a cohort that underwent adjuvant chemotherapy.

5 The high $C P L X 1$ group was likely to have a higher cumulative peritoneal recurrence rate than low $C P L X 1$ group $(P=0.047)$, but this is not the case for liver or nodal recurrence (Fig. $4 \mathrm{c})$. The univariate Cox hazard model showed that high CPLXI expression was not significant but tend to be a high-risk factor for peritoneal recurrence in cohorts having chemotherapy (hazard ratio, $3.139(0.95-10.33) ; P$ $=0.062$ ). Since the factor tumor diameter $<50 \mathrm{~mm}$ being a possible confounder of $C P L X 1, C P L X 1$ was included in multivariate analysis with tumor diameter to demonstrate that high CPLX1 expression was one of the independent risk factors for peritoneal recurrence (hazard ratio, $3.356(1.006-11.2) ; P=$ 0.049) (Table 2).

\section{Discussion}

The prognosis of gastric cancer remains unsatisfactory, and the diagnostic and therapeutic strategy for recurrence has not been developed substantially. Here, we uncovered that CPLX1 was distinctly overexpressed in primary tumor tissues of stage III gastric cancer that recurred despite treatment with curative resection and subsequent chemotherapy with an oral fluorinated pyrimidine. Subsequent qRTPCR analysis of 180 gastric cancer tissues validated the discovery by showing that higher CPLXI expression correlates with a worse prognosis especially in terms of peritoneal recurrence after adjuvant chemotherapy with oral fluoropyrimidine. Our knockdown assays suggested that $C P L X 1$ expression in a gastric cancer cell line promotes malignant phenotypes, such as evading apoptosis, migration, and invasion into extracellular matrix. The drug sensitivity test showed that $C P L X 1$ is not only a candidate biomarker predicting resistance to chemotherapy, but also may have functional aspects of resistance to fluorinated pyrimidines.

Present transcriptomic analysis was attentively designed with limit of UICC stage III gastric 
medRxiv preprint doi: https://doi.org/10.1101/2021.03.25.21254204; this version posted March 28, 2021. The copyright holder for this preprint (which was not certified by peer review) is the author/funder, who has granted medRxiv a license to display the preprint in It is made available under a CC-BY-NC-ND 4.0 International license .

cancer patients who underwent adjuvant chemotherapy with fluorinated pyrimidine and whose prognosis was well-surveyed (i.e., more than 5 years for controls). This approach enabled us to identify genes associated with gastric cancer recurrence under specific circumstances. Some of 12 candidate upregulate genes were reported as oncogenes in the literature. In particular, ASCL2 was already reported as a promoter of chemo-resistance. ${ }^{25} C P L X 1$ was chosen for further investigation as a novel oncogene candidates which has never been reported before. In general, cancer cells can obtain two different drug resistance mechanisms: primary and secondary acquired mechanisms. ${ }^{8}$ In the present study, we focused on the former and hypothesized that disseminated and anoikic cancer cells have a similar gene profile with the primary tumor, which would determine if they are able to survive under exposure to a cytotoxic agent.

In the present study, we applied GR metrics developed by Hafner et al. to evaluate the

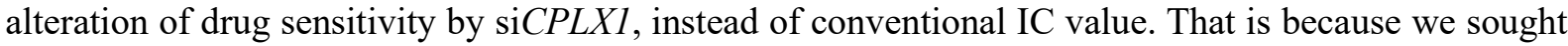
to see the effect of $C P L X 1$ on drug sensitivity by adjusting confounders of proliferation. $\mathrm{IC}_{50}$ can vary drastically if control cells untreated by cytotoxic agents have different division rates among perturbations (i.e., untransfected, siControl, and siCPLXI) during an assay. ${ }^{21}$ The GR value is the ratio of treated cell growth rate to that of untreated cells which are normalized to the cell division. $\mathrm{GR}_{50}$ yielded by GR metrics is robust and largely independent of cell division rate and assay duration.

CPLX1 gene resides on human chromosome 4p16.3 and codes complexin-1 and is a key protein to conduct neurotransmission via synaptic vesicle cycle (VC). ${ }^{26,27}$ CPLXI is dominantly expressed at cytosol of the central nervous system ${ }^{28}$. CPLXI clamps two plasma membranes and activates soluble N-ethylmaleimide sensitive factor attachment protein receptor (SNARE) complex, followed by being released from the unit by synaptotagmin, which allows endocytosis and exocytosis to be completed..$^{26,27}$ The dynamics and physiological roles of VC are so diverse depending on cell types that $\mathrm{VC}$ can promote cell migration through turnover of adhesion receptors, such as integrins, and switch points of attachment to extracellular matrix. ${ }^{29-31}$ It has also been reported that CPLX2, an important paralog of $C P L X 1$, contributes to translocation of GLUT4 to cell membrane through VC. ${ }^{32}$ 
medRxiv preprint doi: https://doi.org/10.1101/2021.03.25.21254204; this version posted March 28, 2021. The copyright holder for this preprint (which was not certified by peer review) is the author/funder, who has granted medRxiv a license to display the preprint in It is made available under a CC-BY-NC-ND 4.0 International license .

However, any oncogenic phenotypes or pathways mediated by $C P L X 1$ have not ever been reported. In the present study, several functional assays revealed that $C P L X 1$ promotes cell motility, cell survival, and cell proliferation even under fluoropyrimidine. These results and the literature on VC support that mechanisms in which $C P L X 1$ plays might be the extension of the cell border through VC. Bringing adhesion receptors onto the plasma membrane through VC may also enhance anti-anoikic and growth signal transduction. ${ }^{33}$ To explore molecular interactions with $C P L X 1$, we performed array-based gene expressional and phosphorylation profiling. ERBB3 is a transmembrane protein, which can initiate signals for cancer progression. ${ }^{34}$ CTNNB1, SNAI3, and SOX10 are transcriptional factors to promote EMT. ${ }^{35-37}$ Through this co-expression, CPLX1 may promote bringing a receptor to the cell surface to initiate transduction of cell growth and EMT signals. Phosphorylated PRAS40-thr246 mediates PIP3-dependent mTORC1 activation with Akt-thr308, which was modestly evident in this study. ${ }^{38,39}$ Increased phosphorylation of p38 and PARP by inhibition of $C P L X 1$ may reflect activated apoptotic response ${ }^{40}$ Taken together, our result suggested that $C P L X 1$ promotes malignant phenotypes in gastric cancer cells, although the molecules, pathways, and their interactions with $C P L X 1$ should be investigated more.

Our epidemiological data suggested that $C P L X 1$ may be a biomarker predicting recurrence of stage II-III gastric cancer, especially peritoneal recurrence despite surgery followed by oral fluoropyrimidine. These high-risk patients may have a chance to undergo more intensive chemotherapy after surgery or even prior to surgery by measuring $C P L X 1$ expression in the primary tumor. Two adjuvant chemotherapy regimens of oral fluoropyrimidine (S-1) monotherapy and Capecitabine plus Oxaliplatin have been standard in East Asia so far. ${ }^{41-43}$ However, oral fluoropyrimidine monotherapy for stage III has been considered to be less effective than for stage II. ${ }^{44}$ Several clinical trials have been conducted to seek survival benefit from more intensive regimens than the monotherapy. ${ }^{44,45} \mathrm{We}$ might be able to select a high-risk cohort who can benefit from those aggressive regimens by measuring $C P L X 1$ expression. We also might be able to develop a molecular-targeted drug for CPLXI combined with fluoropyrimidines. 
medRxiv preprint doi: https://doi.org/10.1101/2021.03.25.21254204; this version posted March 28, 2021. The copyright holder for this

preprint (which was not certified by peer review) is the author/funder, who has granted medRxiv a license to display the preprint in It is made available under a CC-BY-NC-ND 4.0 International license .

The present study has certain limitations. First, the present data about CPLXI mRNA expression data was retrospectively collected from a single institution, and the cut-off value for high $C P L X 1$ expression was exploratorily defined. Second, mechanisms of how CPLX1 promote malignant phenotypes of gastric cancer should be investigated more. In particular, the dynamic behavior of CPLX1 and relation with cancer progression molecules in cancer cell should be further investigated. For example, visualizing that $C P L X 1$ protein (Complexin-1) and EMT-associated molecules are colocalized and demonstrating alteration of VC by siCPLXI in cancer cells would prove our postulation. Moreover, experiments with forced expression of $C P L X 1$ and in vivo experiments are preferable to be done to confirm that $C P L X 1$ promotes malignant phenotypes and plays a role in drug resistance. predicting recurrence after curative resection of gastric cancer followed by adjuvant chemotherapy. In addition, CPLX1 promotes malignant phenotypes and may be a therapeutic target to prevent the recurrence of gastric cancer.

\section{Figure Legends}

Fig. 1. CPLX1 was identified as a putative oncogene to promote the recurrence of gastric cancer.

(a) Extraction diagram demonstrating candidate genes identified by transcriptome analysis. Expressions of 57,749 genes were compared between those who were free from recurrence and those who experienced recurrences of gastric cancer within 2 years. (b) Log-ratio and mean average (MA) plot of expression levels between no recurrence group and early recurrence group yielded twelve candidates of oncogenes. Differentially expressed genes (DEGs) were indicated by magenta (up-regulated in the early recurrence group) and green (down-regulated). (c) RNA expressional heatmap of surgically resected specimens of stage III gastric cancer and adjuvant oral fluoropyrimidine monotherapy. Up-regulated, protein-coding 12 DEGs were listed on right. FC, fold change; CPM, counts per million.

Fig. 2. CPLX1 promotes malignant phenotypes of gastric cancer cell lines. (a) $C P L X 1$ expression 
medRxiv preprint doi: https://doi.org/10.1101/2021.03.25.21254204; this version posted March 28, 2021. The copyright holder for this

preprint (which was not certified by peer review) is the author/funder, who has granted medRxiv a license to display the preprint in It is made available under a CC-BY-NC-ND 4.0 International license .

levels of mRNA on 14 gastric cancer (GC) cell lines and FHs74, nontumorigenic tubular epithelial cell line. (b) CPLXI-knockdown effect on three GC cell lines at mRNA levels. (c) Proliferation assay comparing those four GC cell lines between untreated, transfected by siControl and siCPLXI.

Apoptotic cell observation (d) at cultured on dishes through a phase-contrast microscope, and (e) by staining with annexin-V (See supplemental Fig. S2a). Those four GC cell lines were compared between untreated, treated by siControl, treated by siCPLX1. Cells treated by UV-irradiation were positive controls. (f) Migration assay and (g) invasion assay on AGS cells. $* P<0.05$, ${ }^{* *} P<0.01$, $* * * P<0.001$.

Fig. 3 Effect of CPLX1 inhibition on drug sensitivity and exploring co-expressed genes with CPLX1. (a) Drug sensitivity test comparing between untransfected, and transfected by siContorl and transfected by siCPLXI on four different cells. GR values indicate values calculated by normalized growth rate inhibition (GR) metrics. (b) PCR-based EMT-related 84 genes profiling to test co-expression with CPLX1 among 14 GC cell lines. Significances of coefficients were tested with Spearman correlation test and coefficients degree were represented by rho ( $\rho$ ) values. (c) Pathway analysis with PathScan, sandwich ELISA based immunoassay comparing KATOIII cells untreated, treated by siControl, and siCPLX1. All values were presented with Log2 fold change (Log2FC) from untreated KATOIII cells. Only targets of which absolute values of $\log 2 \mathrm{FCs}(\mathrm{i} . \mathrm{e} .|\log 2 \mathrm{FC}|)$ between untransfected and transfected by siControl are less than 0.5 are presented.

Fig. 4. High $C P L X 1$ expression correlates with the poor survival of patients with gastric cancer. Kaplan-Meier plots of (a) overall survival and (b) recurrence-free survival for the whole cohort ( $\mathrm{n}=$ $180)$ by stratifying with $C P L X 1$ mRNA expression $(C P L X 1 / G A P D H)$. (c) Organ-specific cumulative recurrent plot subgroup receiving adjuvant chemotherapy $(\mathrm{n}=105)$.

\section{Reference}

1. Allemani C, Matsuda T, Di Carlo V, Harewood R, Matz M, Niksic M, Bonaventure A, Valkov 
medRxiv preprint doi: https://doi.org/10.1101/2021.03.25.21254204; this version posted March 28, 2021. The copyright holder for this preprint (which was not certified by peer review) is the author/funder, who has granted medRxiv a license to display the preprint in It is made available under a CC-BY-NC-ND 4.0 International license .

M, Johnson CJ, Esteve J, Ogunbiyi OJ, Azevedo ESG, Chen WQ, Eser S, Engholm G, Stiller CA, Monnereau A, Woods RR, Visser O, Lim GH, Aitken J, Weir HK, Coleman MP. Global surveillance of trends in cancer survival 2000-14 (CONCORD-3): analysis of individual records for 37513025 patients diagnosed with one of 18 cancers from 322 population-based registries in 71 countries. Lancet 2018;391: 1023-75.

2. Ferlay J, Colombet M, Soerjomataram I, Mathers C, Parkin DM, Pineros M, Znaor A, Bray F. Estimating the global cancer incidence and mortality in 2018: GLOBOCAN sources and methods. Int J Cancer 2019;144: 1941-53.

3. Hiki N, Katai H, Mizusawa J, Nakamura K, Nakamori M, Yoshikawa T, Kojima K, Imamoto H, Ninomiya M, Kitano S, Terashima M. Long-term outcomes of laparoscopy-assisted distal gastrectomy with suprapancreatic nodal dissection for clinical stage I gastric cancer: a multicenter phase II trial (JCOG0703). Gastric Cancer 2018;21: 155-61.

4. Shimizu D, Kanda M, Kodera Y, Sakamoto J. Cutting-edge evidence of adjuvant treatments for gastric cancer. Expert Rev Gastroenterol Hepatol 2018;12: 1109-22.

5. Knight G, Earle CC, Cosby R, Coburn N, Youssef Y, Malthaner R, Wong RK. Neoadjuvant or adjuvant therapy for resectable gastric cancer: a systematic review and practice guideline for North America. Gastric Cancer 2013;16: 28-40.

6. Pelcovits A, Almhanna K. Locoregional gastric cancer: a narrative review of multidisciplinary management. Ann Transl Med 2020;8: 1108.

7. Gupta GP, Massague J. Cancer metastasis: building a framework. Cell 2006;127: 679-95.

8. Tolios A, De Las Rivas J, Hovig E, Trouillas P, Scorilas A, Mohr T. Computational approaches in cancer multidrug resistance research: Identification of potential biomarkers, drug targets and drug-target interactions. Drug Resist Updat 2020;48: 100662.

9. Tan P, Yeoh KG. Genetics and Molecular Pathogenesis of Gastric Adenocarcinoma. Gastroenterology 2015;149: 1153-62 e3.

10. Brosnan JA, Iacobuzio-Donahue CA. A new branch on the tree: next-generation sequencing in the study of cancer evolution. Semin Cell Dev Biol 2012;23: 237-42.

11. Redler S, Strom TM, Wieland T, Cremer K, Engels H, Distelmaier F, Schaper J, Küchler A, Lemke JR, Jeschke S, Schreyer N, Sticht H, Koch M, Lüdecke HJ, Wieczorek D. Variants in CPLX1 in two families with autosomal-recessive severe infantile myoclonic epilepsy and ID. Eur J Hum Genet 2017;25: 889-93.

12. Nagy Á, Lánczky A, Menyhárt O, Győrffy B. Validation of miRNA prognostic power in hepatocellular carcinoma using expression data of independent datasets. Sci Rep 2018;8: 9227.

13. Tanaka H, Kanda M, Miwa T, Tanaka C, Kobayashi D, Umeda S, Shibata M, Suenaga M, Hattori N, Hayashi M, Iwata N, Yamada S, Nakayama G, Fujiwara M, Kodera Y. PatternSpecific Transcriptomics Identifies ASGR2 as a Predictor of Hematogenous Recurrence of Gastric Cancer. Mol Cancer Res 2018;16: 1420-9.

14. Tang M, Sun J, Shimizu K, Kadota K. Evaluation of methods for differential expression analysis on multi-group RNA-seq count data. BMC Bioinformatics 2015;16: 361.

15. Tanaka H, Kanda M, Shimizu D, Tanaka C, Kobayashi D, Hayashi M, Iwata N, Yamada S, 
medRxiv preprint doi: https://doi.org/10.1101/2021.03.25.21254204; this version posted March 28, 2021. The copyright holder for this preprint (which was not certified by peer review) is the author/funder, who has granted medRxiv a license to display the preprint in It is made available under a CC-BY-NC-ND 4.0 International license .

Fujii T, Nakayama G, Sugimoto H, Fujiwara M, Niwa Y, Kodera Y. FAM46C Serves as a Predictor of Hepatic Recurrence in Patients with Resectable Gastric Cancer. Ann Surg Oncol 2016;24: 3438-45.

16. Tanaka H KM, Miwa T, Umeda S, Sawaki K, Tanaka C, Kobayashi D, Hayashi M, Yamada S, Nakayama G, Koike M, Kodera Y. G Protein Subunit Gamma 4 Expression Has Potential for Detection, Prediction, and Therapeutic Targeting in Liver Metastasis of Gastric Cancer. British J Cancer 2021; In press.

17. Kanda M, Tanaka H, Shimizu D, Miwa T, Umeda S, Tanaka C, Kobayashi D, Hattori N, Suenaga M, Hayashi M, Iwata N, Yamada S, Fujiwara M, Kodera Y. SYT7 acts as a driver of hepatic metastasis formation of gastric cancer cells. Oncogene 2018;37: 5355-66.

18. Miwa T, Kanda M, Shimizu D, Umeda S, Sawaki K, Tanaka H, Tanaka C, Hattori N, Hayashi M, Yamada S, Nakayama G, Koike M, Kodera Y. Hepatic metastasis of gastric cancer is associated with enhanced expression of ethanolamine kinase 2 via the p53-Bcl-2 intrinsic apoptosis pathway. Br J Cancer 2021.

19. Kanda M, Shimizu D, Tanaka H, Tanaka C, Kobayashi D, Hayashi M, Takami H, Niwa Y, Yamada S, Fujii T, Sugimoto H, Kodera Y. Synaptotagmin XIII expression and peritoneal metastasis in gastric cancer. Br J Surg 2018.

20. Kanda M, Shimizu D, Tanaka H, Tanaka C, Kobayashi D, Hayashi M, Iwata N, Niwa Y, Yamada S, Fujii T, Sugimoto H, Murotani K, Fujiwara M, Kodera Y. Significance of SYT8 For the Detection, Prediction, and Treatment of Peritoneal Metastasis From Gastric Cancer. Ann Surg 2016;267: 495-503.

21. Hafner M, Niepel M, Chung M, Sorger PK. Growth rate inhibition metrics correct for confounders in measuring sensitivity to cancer drugs. Nat Methods 2016;13: 521-7.

22. Kanda M, Shimizu D, Sawaki K, Nakamura S, Umeda S, Miwa T, Tanaka H, Tanaka C, Hayashi M, Iguchi Y, Yamada S, Katsuno M, Kodera Y. Therapeutic monoclonal antibody targeting of neuronal pentraxin receptor to control metastasis in gastric cancer. Mol Cancer 2020;19: 131 .

23. Umeda S, Kanda M, Miwa T, Tanaka H, Tanaka C, Kobayashi D, Hayashi M, Yamada S, Nakayama G, Koike M, Kodera Y. Fraser extracellular matrix complex subunit 1 promotes liver metastasis of gastric cancer. Int $J$ Cancer 2020;146: 2865-76.

24. Sharma S, Ghufran SM, Ghose S, Biswas S. Cytoplasmic vacuolation with endoplasmic reticulum stress directs sorafenib induced non-apoptotic cell death in hepatic stellate cells. $S c i$ Rep 2021;11: 3089.

25. Kwon OH, Park JL, Baek SJ, Noh SM, Song KS, Kim SY, Kim YS. Aberrant upregulation of ASCL2 by promoter demethylation promotes the growth and resistance to 5-fluorouracil of gastric cancer cells. Cancer Sci 2013;104: 391-7.

26. Rizo J, Rosenmund C. Synaptic vesicle fusion. Nat Struct Mol Biol 2008;15: 665-74.

27. Südhof TC, Rothman JE. Membrane fusion: grappling with SNARE and SM proteins. Science 2009;323: 474-7. 
medRxiv preprint doi: https://doi.org/10.1101/2021.03.25.21254204; this version posted March 28, 2021. The copyright holder for this preprint (which was not certified by peer review) is the author/funder, who has granted medRxiv a license to display the preprint in It is made available under a CC-BY-NC-ND 4.0 International license .

4221-35.

29. Kasai H, Takahashi N, Tokumaru H. Distinct initial SNARE configurations underlying the diversity of exocytosis. Physiol Rev 2012;92: 1915-64.

30. Lawson MA, Maxfield FR. Ca(2+)- and calcineurin-dependent recycling of an integrin to the front of migrating neutrophils. Nature 1995;377: 75-9.

31. Proux-Gillardeaux V, Gavard J, Irinopoulou T, Mège RM, Galli T. Tetanus neurotoxin-mediated cleavage of cellubrevin impairs epithelial cell migration and integrin-dependent cell adhesion. Proc Natl Acad Sci US A 2005;102: 6362-7.

32. Pavarotti MA, Tokarz V, Frendo-Cumbo S, Bilan P, Liu Z, Zanni-Ruiz E, Mayorga LS, Klip A. Complexin-2 redistributes to the membrane of muscle cells in response to insulin and contributes to GLUT4 translocation. Biochem J 2021.

33. Desiniotis A, Kyprianou N. Significance of talin in cancer progression and metastasis. Int Rev Cell Mol Biol 2011;289: 117-47.

34. Kim J, Jeong H, Lee Y, Kim C, Kim H, Kim A. HRG-61-driven ErbB3 signaling induces epithelial-mesenchymal transition in breast cancer cells. BMC Cancer 2013;13: 383.

35. Yilmaz M, Christofori G. EMT, the cytoskeleton, and cancer cell invasion. Cancer Metastasis Rev 2009;28: 15-33.

36. Wu C, Ding H, Wang S, Li Y, Liu SB, Wang X, Zheng J, Xue T, Amin HM, Song YH, Zhou J. DAXX inhibits cancer stemness and epithelial-mesenchymal transition in gastric cancer. $B r J$ Cancer 2020;122: 1477-85.

37. Yu L, Peng F, Dong X, Chen Y, Sun D, Jiang S, Deng C. Sex-Determining Region Y Chromosome-Related High-Mobility-Group Box 10 in Cancer: A Potential Therapeutic Target. Front Cell Dev Biol 2020;8: 564740.

38. Vander Haar E, Lee SI, Bandhakavi S, Griffin TJ, Kim DH. Insulin signalling to mTOR mediated by the Akt/PKB substrate PRAS40. Nat Cell Biol 2007;9: 316-23.

39. Figueiredo VC, Markworth JF, Cameron-Smith D. Considerations on mTOR regulation at serine 2448: implications for muscle metabolism studies. Cell Mol Life Sci 2017;74: 2537-45.

40. Mehta SL, Manhas N, Raghubir R. Molecular targets in cerebral ischemia for developing novel therapeutics. Brain Res Rev 2007;54: 34-66.

41. Sasako M, Sakuramoto S, Katai H, Kinoshita T, Furukawa H, Yamaguchi T, Nashimoto A, Fujii M, Nakajima T, Ohashi Y. Five-year outcomes of a randomized phase III trial comparing adjuvant chemotherapy with S-1 versus surgery alone in stage II or III gastric cancer. $J C l i n$ Oncol 2011;29: 4387-93.

42. Noh SH, Park SR, Yang HK, Chung HC, Chung IJ, Kim SW, Kim HH, Choi JH, Kim HK, Yu W, Lee JI, Shin DB, Ji J, Chen JS, Lim Y, Ha S, Bang YJ. Adjuvant capecitabine plus oxaliplatin for gastric cancer after D2 gastrectomy (CLASSIC): 5-year follow-up of an open-label, randomised phase 3 trial. Lancet Oncol 2014;15: 1389-96.

43. Kanda M, Suh YS, Park DJ, Tanaka C, Ahn SH, Kong SH, Lee HJ, Kobayashi D, Fujiwara M, Shimada H, Cho B, Murotani K, Kim HH, Yang HK, Kodera Y. Serum levels of ANOS1 serve as a diagnostic biomarker of gastric cancer: a prospective multicenter observational study. 
medRxiv preprint doi: https://doi.org/10.1101/2021.03.25.21254204; this version posted March 28, 2021. The copyright holder for this preprint (which was not certified by peer review) is the author/funder, who has granted medRxiv a license to display the preprint in It is made available under a CC-BY-NC-ND 4.0 International license .

Gastric Cancer 2020;23: 203-11.

44. Terashima M, Yoshikawa T, Boku N, Ito S, Tsuburaya A, Iwasaki Y, Fukagawa T, Tokunaga M, Sano T, Sasako M. Current status of perioperative chemotherapy for locally advanced gastric cancer and JCOG perspectives. Jpn J Clin Oncol 2020;50: 528-34.

45. Yoshida K, Kodera Y, Kochi M, Ichikawa W, Kakeji Y, Sano T, Nagao N, Takahashi M, Takagane A, Watanabe T, Kaji M, Okitsu H, Nomura T, Matsui T, Yoshikawa T, Matsuyama J, Yamada M, Ito S, Takeuchi M, Fujii M. Addition of Docetaxel to Oral Fluoropyrimidine Improves Efficacy in Patients With Stage III Gastric Cancer: Interim Analysis of JACCRO GC-07, a Randomized Controlled Trial. J Clin Oncol 2019;37: 1296-304. 
Fig. 1

a

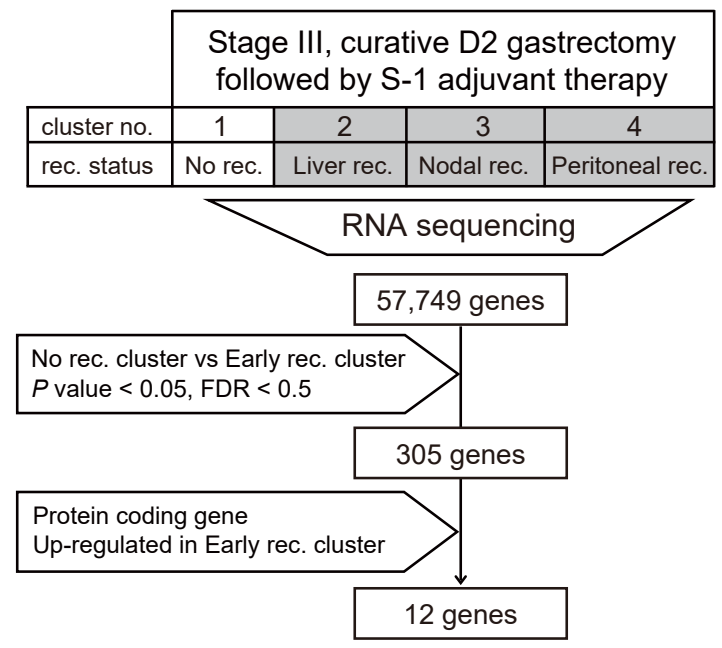

b

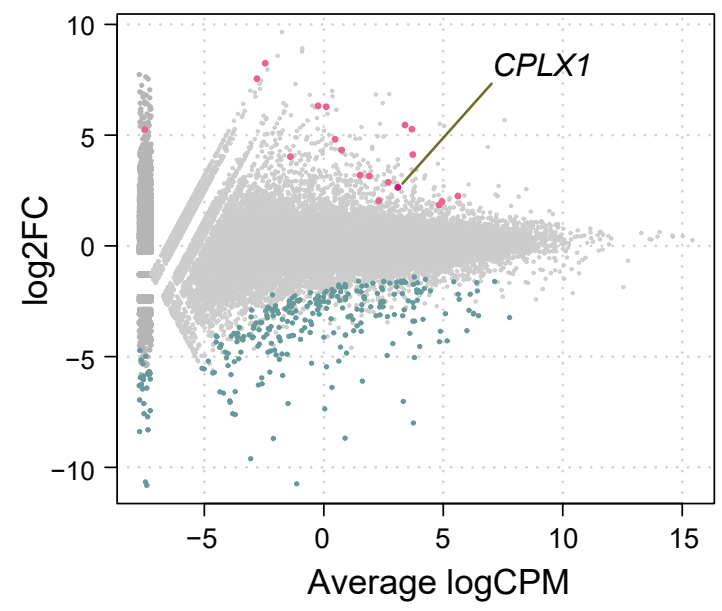

C

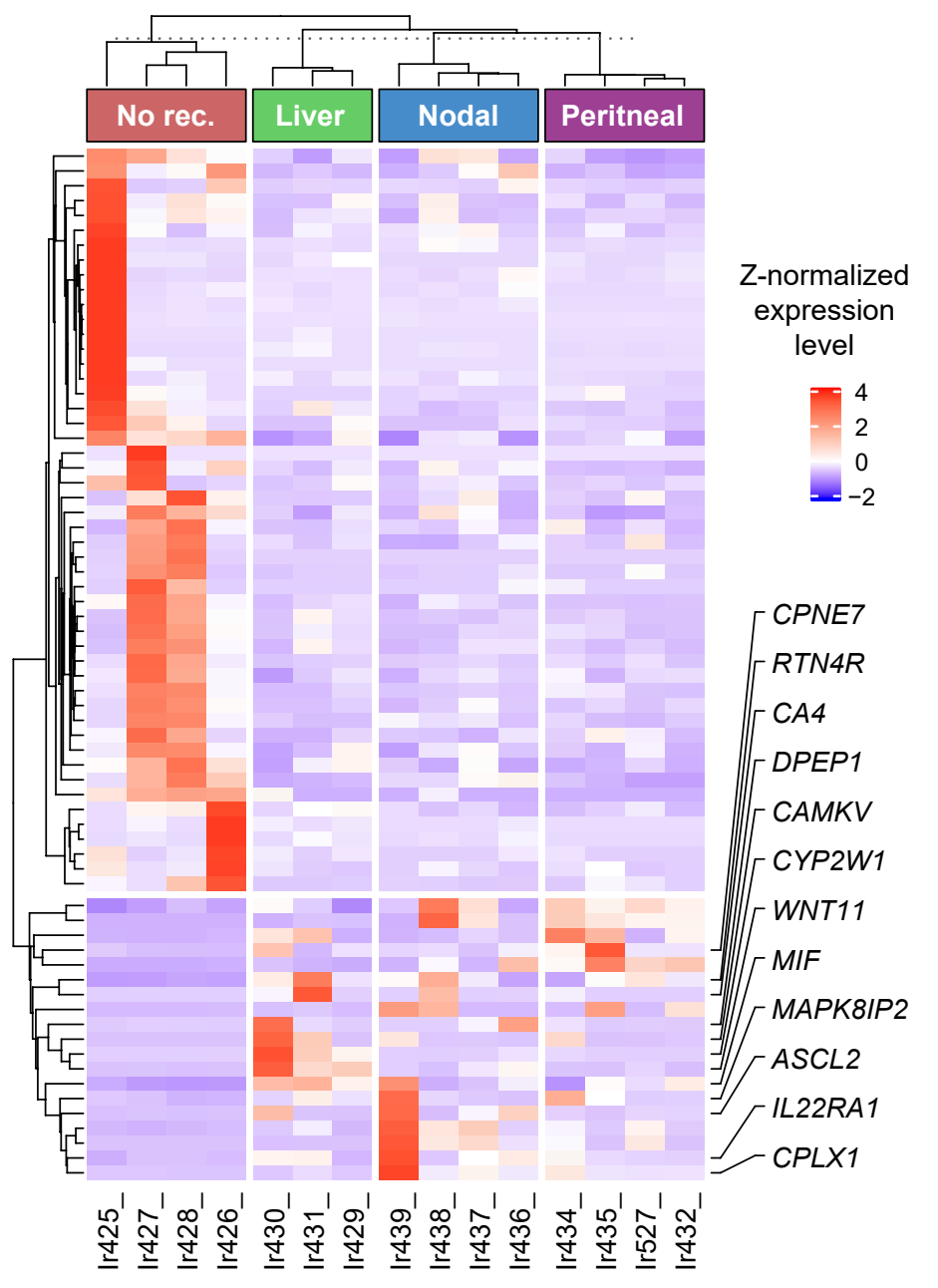

Fig. 1. CPLX1 was identified as a putative oncogene to promote the recurrence of gastric cancer. (a) Extraction diagram demonstrating candidate genes identified by transcriptome analysis. Expressions of 57,749 genes were compared between those who were free from recurrence and those who experienced recurrences of gastric cancer within 2 years. (b) Log-ratio and mean average (MA) plot of expression levels between no recurrence group and early recurrence group yielded twelve candidates of oncogenes. Differentially expressed genes (DEGs) were indicated by magenta (up-regulated in the early recurrence group) and green (down-regulated). (c) RNA expressional heatmap of surgically resected specimens of stage III gastric cancer and adjuvant oral fluoropyrimidine monotherapy. Up-regulated, proteincoding 12 DEGs were listed on right. FC, fold change; CPM, counts per million. 
Fig. 2

a

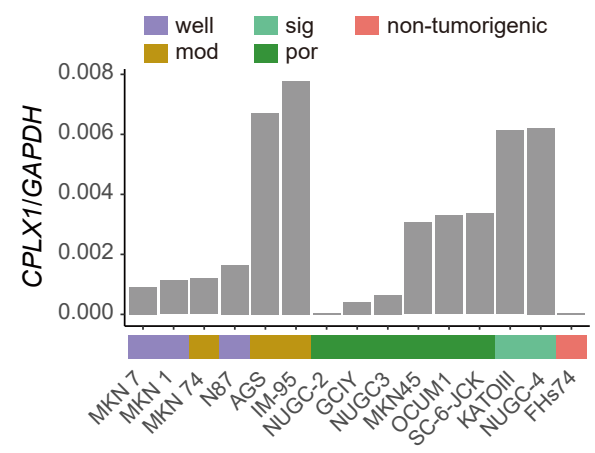

b

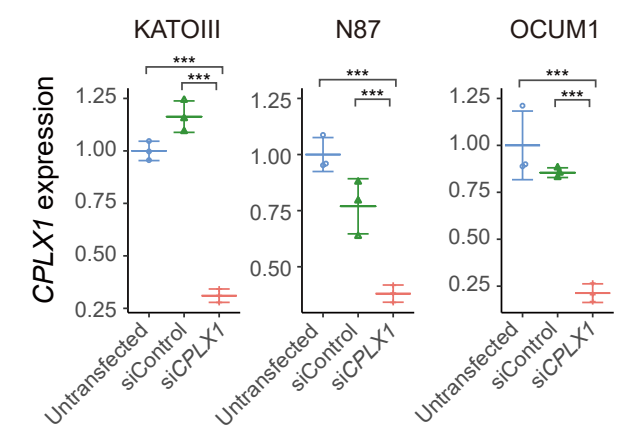

f
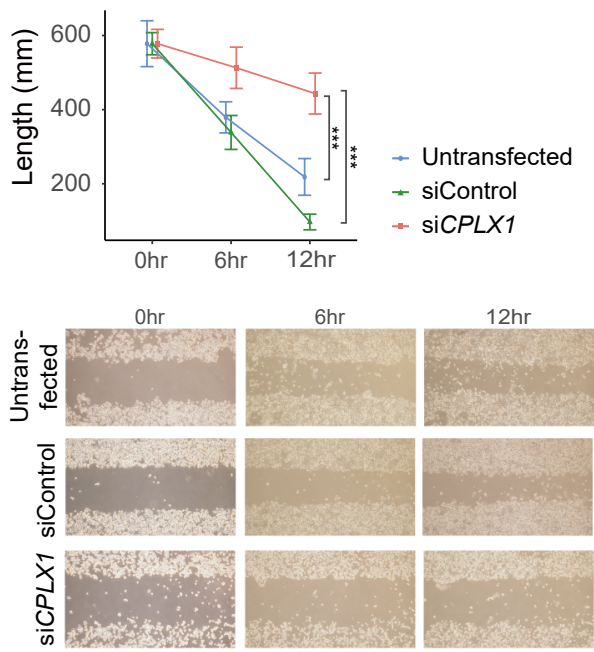

C
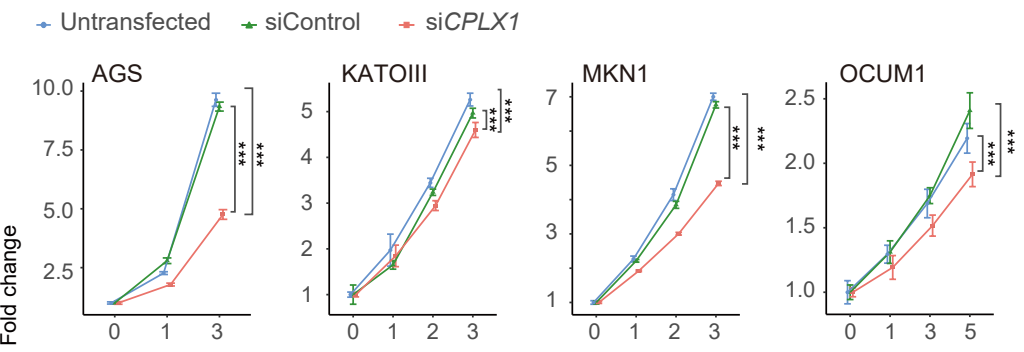

Day

d
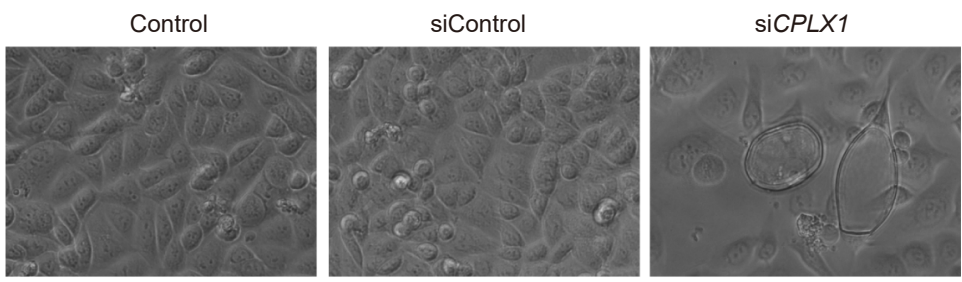

e
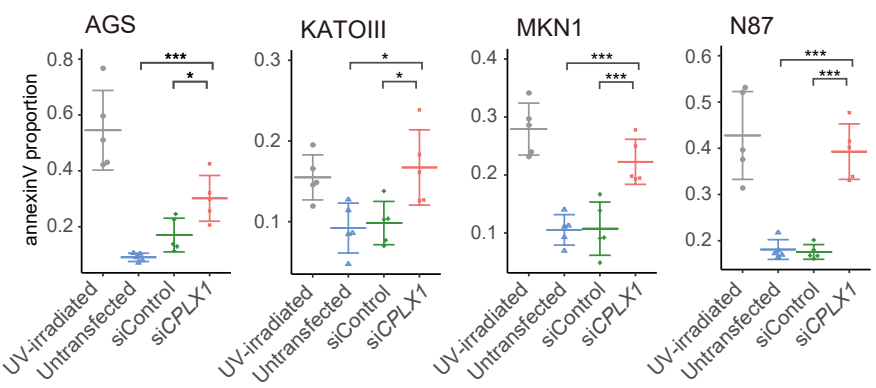

g
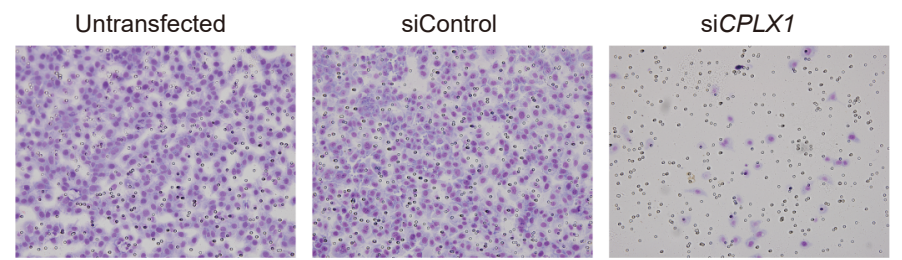

Fig. 2. CPLX1 promotes malignant phenotypes of gastric cancer cell lines. (a) CPLX1 expression levels of mRNA on 14 gastric cancer (GC) cell lines and FHs74, nontumorigenic tubular epithelial cell line. (b) CPLX1-knockdown effect on three GC cell lines at mRNA levels. (c) Proliferation assay comparing those four GC cell lines between untreated, transfected by siControl and siCPLX1. Apoptotic cell observation (d) at cultured on dishes through a phase-contrast microscope, and (e) by staining with annexin- $V$. Those four GC cell lines were compared between untreated, treated by siControl, treated by siCPLX1. Cells treated by UV-irradiation were positive controls. (f) Migration assay and (g) invasion assay on AGS cells. ${ }^{*} \mathrm{P}<0.05,{ }^{* *} \mathrm{P}<0.01,{ }^{* *} \mathrm{P}<0.001$. 
Fig. 3

a
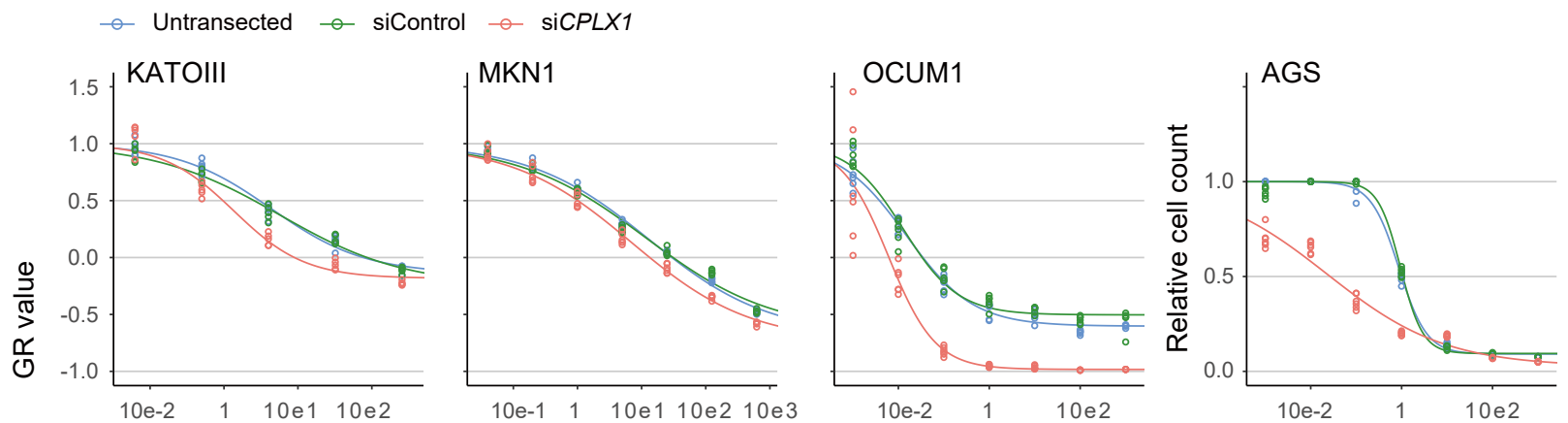

5-FU Concentration $(\mu \mathrm{g} / \mathrm{mL})$

GR50 (95\% Cl)

\begin{tabular}{lccc} 
& \multicolumn{3}{c}{ KR50 $(95 \%$ Cl } \\
\cline { 2 - 4 } & KATOIII & MKN1 & OCUM1 \\
Untrasfected & $4.35(1.97-6.74)$ & $13.1(7.03-19.1)$ & $0.015(0.009-0.020)$ \\
siControl & $5.65(0.582-10.7)$ & $11.6(5.30-17.8)$ & $0.013(0.008-0.018)$ \\
siCPLX1 & $1.37(0.927-1.80)$ & $7.02(4.42-9.61)$ & $0.006(0.005-0.007)$
\end{tabular}

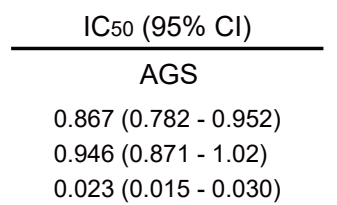

C

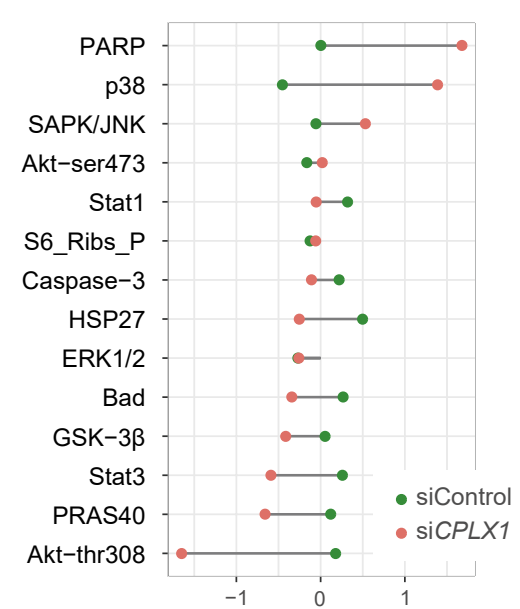

Expression alteration (Log2 Fold Change)

CPLX1
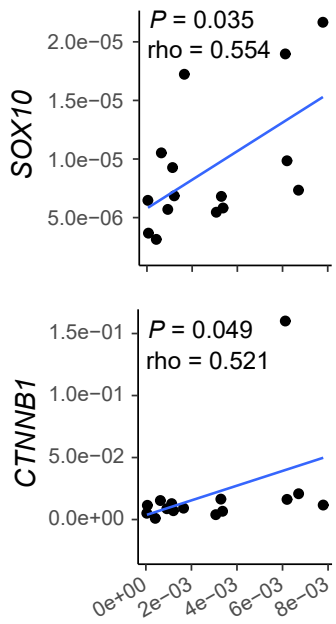
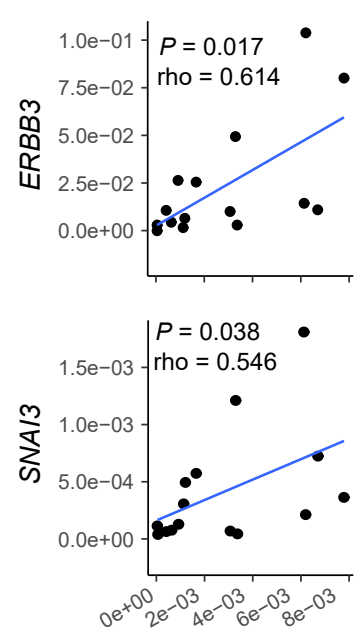

온

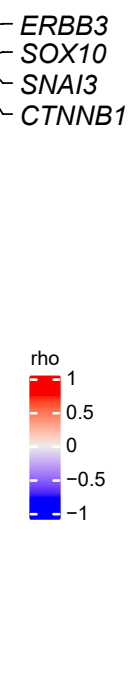

Fig. 3 Effect of CPLX1 inhibition on drug sensitivity and exploring co-expressed genes with CPLX1. (a) Drug sensitivity test comparing between untransfected, and transfected by siContorl and transfected by siCPLX1 on four different cells. GR values indicate values calculated by normalized growth rate inhibition (GR) metrics. (b) PCR-based EMT-related 84 genes profiling to test coexpression with CPLX1 among 14 GC cell lines. Significances of coefficients were tested with Spearman correlation test and coefficients degree were represented by rho $(\rho)$ values. (c) Pathway analysis with PathScan, sandwich ELISA based immunoassay comparing KATOIII cells untreated, treated by siControl, and siCPLX1. All values were presented with Log2 fold change (Log2FC) from untreated KATOIII cells. Only targets of which absolute values of log2FCs (i.e. |log2FC|) between untransfected and transfected by siControl are less than 0.5 are presented. 
Fig. 4

a

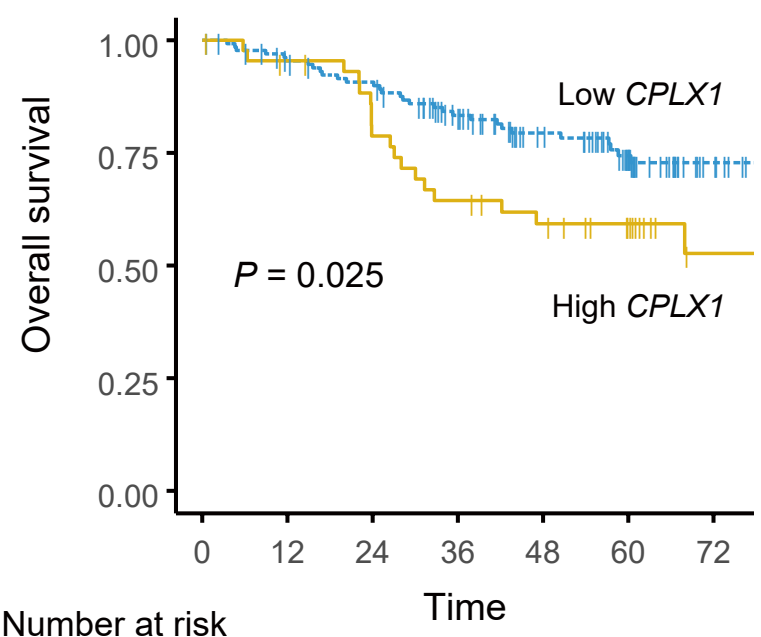

$\begin{array}{llllllll}\text { Low CPLX1 } & 135 & 123 & 115 & 94 & 72 & 51 & 26\end{array}$ $\begin{array}{llllllll}\text { High CPLX1 } & 45 & 41 & 33 & 27 & 23 & 17 & 7\end{array}$

b

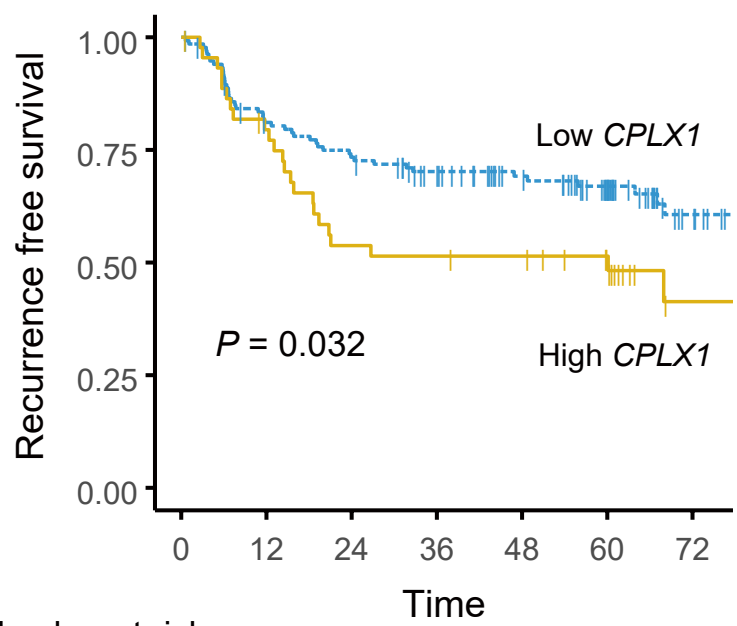

Number at risk

$\begin{array}{lccccccc}\text { Low CPLX1 } & 135 & 105 & 95 & 83 & 67 & 49 & 23 \\ \text { High CPLX1 } & 45 & 34 & 23 & 22 & 21 & 16 & 5\end{array}$

C
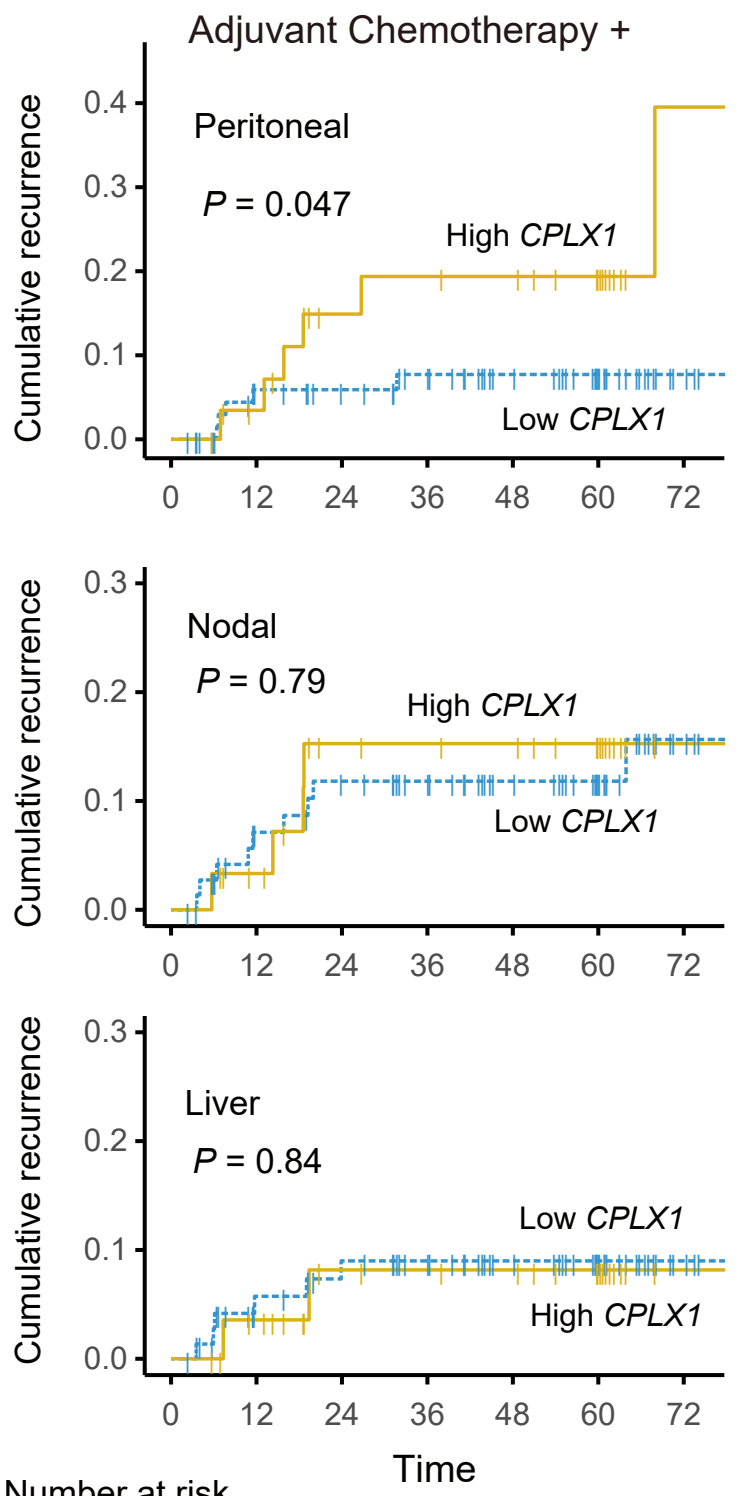

Number at risk

$\begin{array}{llllllll}\text { Low CPLX1 } & 75 & 60 & 55 & 49 & 39 & 28 & 14 \\ \text { High CPLX1 } & 30 & 26 & 19 & 18 & 17 & 12 & 3\end{array}$

Fig. 4. High CPLX1 expression correlates with the poor survival of patients with gastric cancer. Kaplan-Meier plots of (a) overall survival and $(b)$ recurrence-free survival for the whole cohort $(n=180)$ by stratifying with CPLX1 mRNA expression $(C P L X 1 / G A P D H)$.

(c) Organ-specific cumulative recurrent plot subgroup receiving adjuvant chemotherapy $(n=105)$. 
medRxiv preprint doi: https://doi.org/10.1101/2021.03.25.21254204; this version posted March 28, 2021. The copyright holder for this preprint (which was not certified by peer review) is the author/funder, who has granted medRxiv a license to display the preprint in It is made available under a CC-BY-NC-ND 4.0 International license .

Table 1. clinicopathological characteristics of stage II-III gastric cancer $(n=180)$

\begin{tabular}{|c|c|c|c|}
\hline variables & $\begin{array}{c}\text { Low } C P L X 1 \\
n=135\end{array}$ & $\begin{array}{c}\text { High } C P L X 1 \\
n=45\end{array}$ & $\boldsymbol{P}$ \\
\hline Age (years old, mean (SD)) & $67.09(11.85)$ & $65.89(7.99)$ & 0.528 \\
\hline Sex; female/male (\%) & $37 / 98(27.4 / 72.6)$ & $14 / 31(31.1 / 68.9)$ & 0.703 \\
\hline CA19-9 (IU/mL, median [IQR]) & $13.00[7.00,28.50]$ & $16.00[10.00,33.00]$ & 0.334 \\
\hline CEA (ng/mL, median [IQR]) & $2.40[1.50,3.60]$ & $2.80[1.70,4.20]$ & 0.214 \\
\hline Tumor diameter (mm, mean (SD)) & $53.40(27.36)$ & $64.18(35.62)$ & 0.036 \\
\hline Tumor location (\%) & & & 0.034 \\
\hline Upper third & $33(24.4)$ & $18(40.0)$ & \\
\hline Middle third & $48(35.6)$ & $16(35.6)$ & \\
\hline Lower third & $50(37.0)$ & $8(17.8)$ & \\
\hline Diffuse & $4(3.0)$ & $3(6.7)$ & \\
\hline Borrman type $1-3 / 4-5(\%)$ & $123 / 12(91.1 / 8.9)$ & $37 / 8(82.2 / 17.8)$ & 0.108 \\
\hline Undifferentiated/Differented (\%) & $84 / 51(62.2 / 37.8)$ & $28 / 17(62.2 / 37.8)$ & 1 \\
\hline Growth type; expansive/invasive (\%) & $84 / 51(62.2 / 37.8)$ & $32 / 13(71.1 / 28.9)$ & 0.369 \\
\hline Vessel invasion; absent/present (\%) & $37 / 98(27.4 / 72.6)$ & $8 / 37(17.8 / 82.2)$ & 0.236 \\
\hline UICC Stage; II/III (\%) & $57 / 78(42.2 / 57.8)$ & $14 / 31(31.1 / 68.9)$ & 0.22 \\
\hline T-stage; T1-3/T4 (\%) & $74 / 61(54.8 / 45.2)$ & $23 / 22(51.1 / 48.9)$ & 0.731 \\
\hline N-stage; negative/positive (\%) & $31 / 104(23.0 / 77.0)$ & $8 / 37(17.8 / 82.2)$ & 0.536 \\
\hline
\end{tabular}

CA19-9, Carbohydrate Antigen 19-9; CEA, Carcinoembryonic antigen; IQR, inter quartile range 
medRxiv preprint doi: https://doi.org/10.1101/2021.03.25.21254204; this version posted March 28, 2021. The copyright holder for this preprint (which was not certified by peer review) is the author/funder, who has granted medRxiv a license to display the preprint in It is made available under a CC-BY-NC-ND 4.0 International license .

Table 2. COX hazard model analysis for peritoneal recurrence after adjuvant chemotherapy

\begin{tabular}{lcccc}
\hline Variable & coefficient & $P$ & coefficient & $P$ \\
\hline Age $>65$ years old & $0.654(0.19-2.24)$ & 0.492 & & \\
Male sex & $0.622(0.19-2.06)$ & 0.442 & & \\
Tumor size $>50 \mathrm{~mm}$ & $8.403(1.08-65.71)$ & $0.008^{*}$ & $5.465(0.69-43.54)$ & 0.109 \\
Tumor location (upper third) & $1.32(0.35-4.98)$ & 0.688 & & \\
CA19-9 $>37$ IU/mL & $0.496(0.063-3.874)$ & 0.461 & & \\
CEA $>5$ ng/mL & $1.155(0.249-5.348)$ & 0.856 & & \\
Differentiated type & $0.422(0.091-1.959)$ & 0.232 & & \\
Invasive growth type & $7.442(1.60-34.54)$ & $0.003 *$ & $7.531(1.60-35.47)$ & \\
Vessel involvement & $1.295(0.280-6.00)$ & 0.734 & & \\
Tumor depth T4 (vs T1 -3$)$ & $2.371(0.630-8.94)$ & 0.179 & & \\
Lymph node metastasis & NA $(0-$ Inf $)$ & NA & & \\
UICC Stage III & NA $(0-$ Inf $)$ & NA & & \\
High $C P L X 1$ expression & $3.139(0.954-10.3)$ & 0.062 & $3.356(1.01-11.2)$ & \\
\hline
\end{tabular}


medRxiv preprint doi: https://doi.org/10.1101/2021.03.25.21254204; this version posted March 28, 2021. The copyright holder for this preprint (which was not certified by peer review) is the author/funder, who has granted medRxiv a license to display the preprint in It is made available under a CC-BY-NC-ND 4.0 International license .

Supplementary Table S1. Primer sequences

\begin{tabular}{lll}
\hline RT-PCR (93bp) & Forward & Reverse \\
& ATCGCCATGGAGTTTGTGAT (exon 2) & GTCTGGGTCCTTCTCCTCGT (exon 3) \\
\hline siRNA & Sense & Anti-sense \\
si $C P L X 1-1$ & AGGACAUGCUCAAGAAGUA + dTdT & UACUUCUUGAGCAUGUCCU + dTdT \\
si $C P L X 1-2$ & GCAAGGCCAAGUACGCCAA + dTdT & UUGGCGUACUUGGCCUUGC + dTdT \\
si $C P L X 1-3$ & GGAGCUUGACGCGGCCCAA + dTdT & UUGGGCCGCGUCAAGCUCC + dTdT \\
si $C P L X 1-4$ & UCUUGAUGCCGUACUUGUCUC & GACAAGUACGGCAUCAAGAAG
\end{tabular}

RT-PCR, reverse transcription polymerase chain reaction 
a

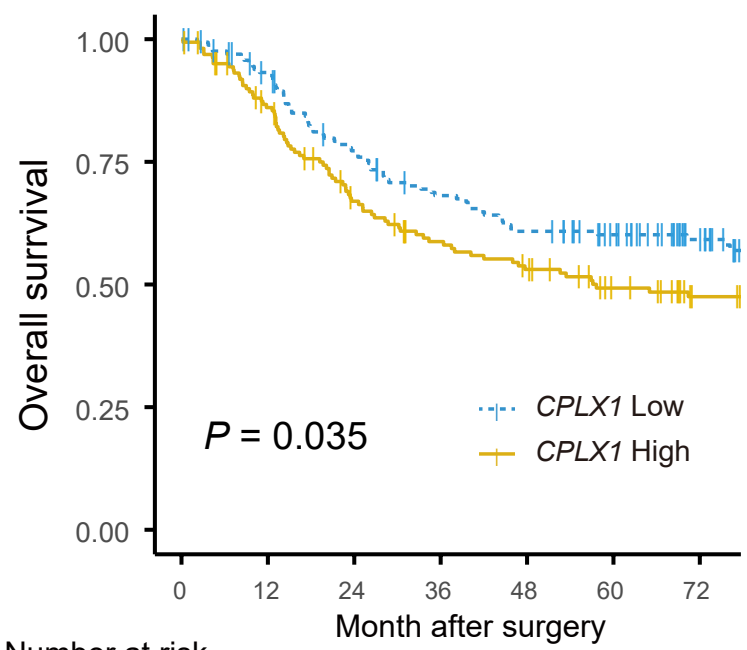

Number at risk

$\begin{array}{cccccccc}\text { CPLX1 Low } & 169 & 148 & 120 & 103 & 92 & 81 & 61 \\ \text { CPLX1 High } & 163 & 133 & 99 & 83 & 74 & 61 & 49\end{array}$

b

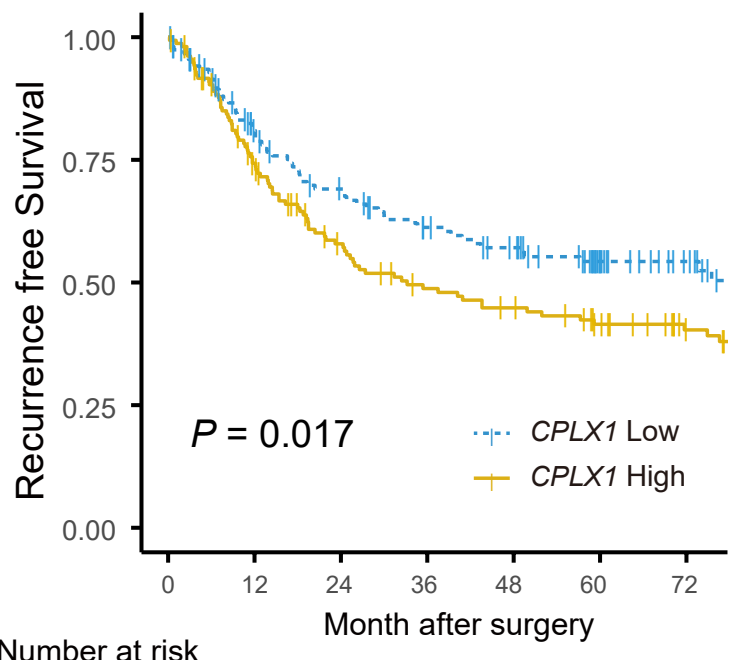

Number at risk

$\begin{array}{llllllll}\text { CPLX1 Low } & 159 & 111 & 90 & 75 & 66 & 45 & 32 \\ \text { CPLX1 High } & 158 & 109 & 77 & 62 & 56 & 46 & 34\end{array}$

Supplemental Fig. S1. Kaplan-Meier plot of (a) overall survival, and (b) progression-free survival using external datasets grouped by the median value of CPLX1. Data were retrieved from the GSE62254, GSE15459, GSE22377, GSE62254, GSE29272, and GSE38749, of which UICC Stages were limited to II-III. 


\section{Supplemental Fig. 2}

a
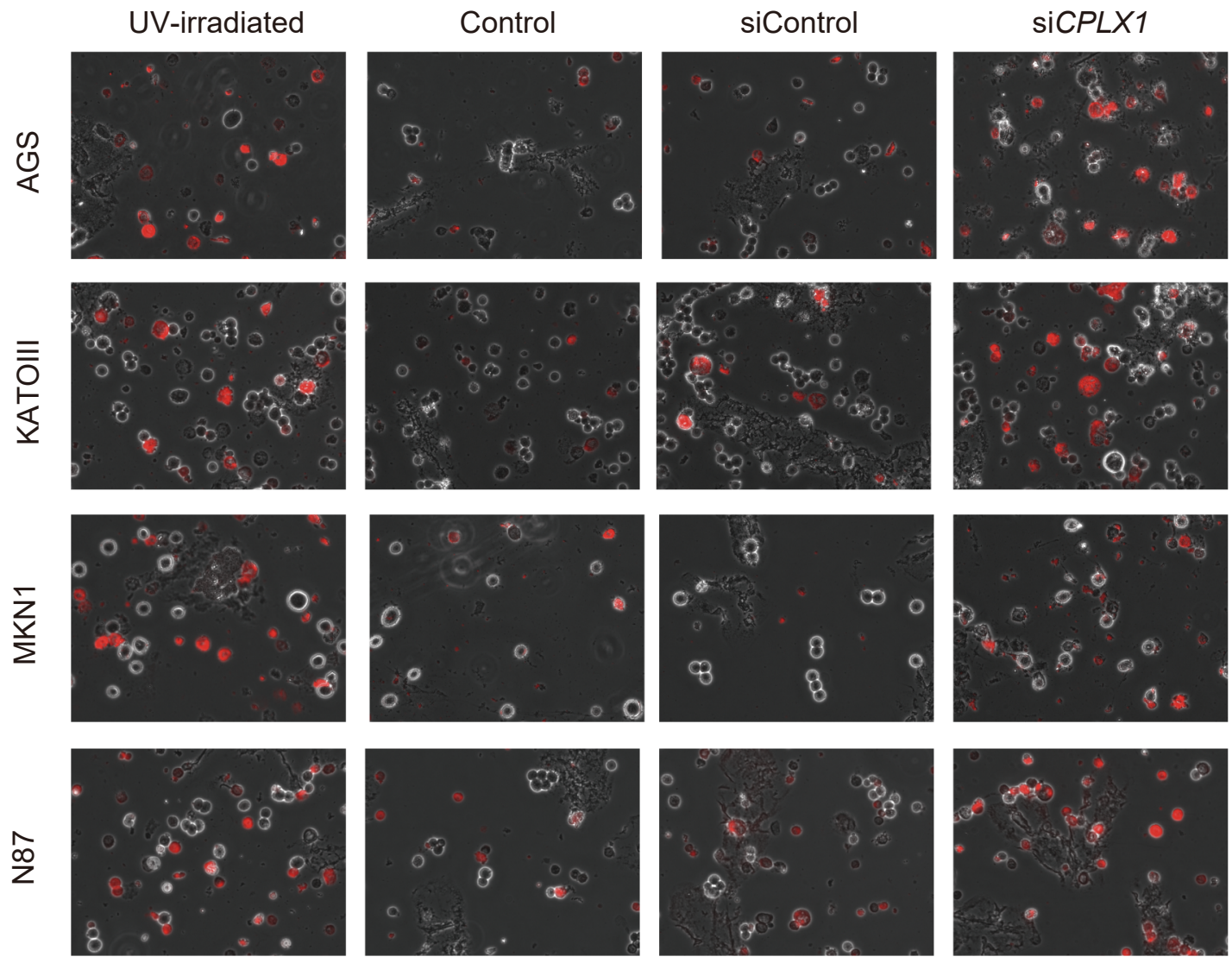

b
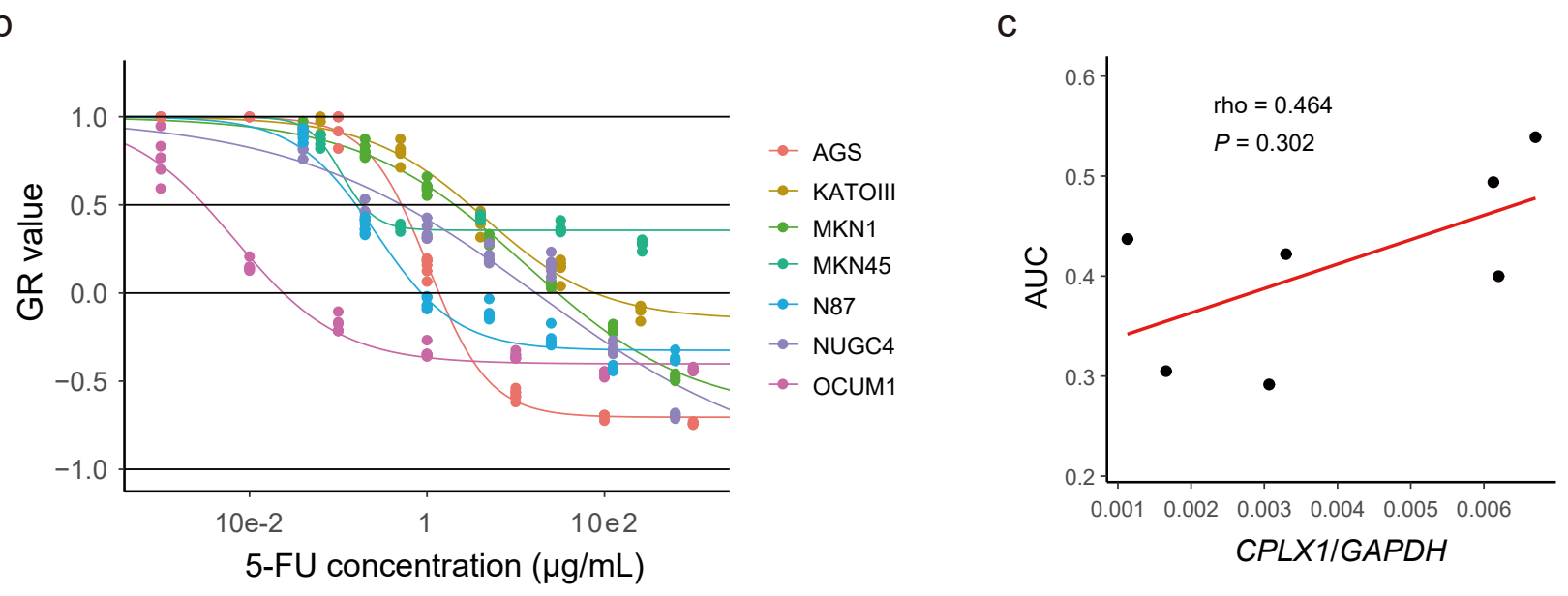

Supplemental Fig. S2. (a) Apoptotic cell detection by staining with annexin-V (See Fig. 2e). Phase-contrast and fluorescence images were merged to be presented. (b) Drug sensitivity tests to fluorouracil (5-FU) on seven gastric cancer (GC) cell lines. GR values indicate values calculated by normalized growth rate inhibition (GR) metrics. (c) Scatter plot between CPLX1 mRNA expression (CPLX1/ $G A P D H$ ) and area under the dose-response curves (AUC) to fluorouracil (5-FU) of seven GC cell lines. A correlation test was done with the Spearman test. 